\title{
Personal Relationships and Higher Agency Costs: Study of Buyers and Suppliers in Australian Manufacturing and Service Sector
}

\author{
Atif Saleem Butt \\ Department of Management \\ Monash University, Victoria, Australia \\ Email: atif627@yahoo.com
}

\begin{abstract}
Personal relationships (i.e. friendships) have been the subject of much research in the business discipline, with the majority of literature focusing on how personal relationships yield positive firm-level outcomes. However, personal relationships are not without drawbacks and may lead to negative outcomes for the firms involved. Despite this, the current body of knowledge on this issue is relatively fragmented. This paper addresses this important gap in the literature. For exploratory purposes, the study is qualitative in nature. Based on a grounded theory approach, a model is developed describing how personal relationships embedded within inter-firm relationships lead to negative outcomes for the firms. Overall, 16 in-depth interviews with seniormanagers of buying and supplying firms were undertaken. Results from this study exhibit that managers engage in exploitation of personal relationships by demanding higher sales commission, higher bonuses and higher salaries from their respective firms, leading to higher agency costs. Firms can use these finding to understand explicitly what types of negative consequences personal relationships yield. Further, this study presents to firms specific actions that managers of buying and supplying firms engage in, when a personal relationship is present between them in the supply chain Finally, this paper concludes by providing several constructive guidelines to firms on managing personal relationships within inter-firm relationships in order to mitigate its negative firm-level consequences.
\end{abstract}

Keywords: supply chain, personal relationships, buyer-supplier relationships

\section{INTRODUCTION}

In today's ultra-competitive business environment, supply chains success primarily depends on the need for firms to develop long-term business relationships. In fact, there is a growing surge in maintaining long-term, inter-firm relationships as management of these relationships have benefits for both parties (Kalwani \& Narayandas, 1995). A buying firm can strengthen its competitiveness and secure access to external resources that the company needs (Golicic \& Mentzer, 2006). A Supplying firm can reach higher profits by maintaining long-term relationships (Kalwani \& Narayandas, 1995). Firms also stress the importance of close relationships because they can achieve additional benefits such as higher levels of partner trust and commitment (Autry and Golicic, 2010; Golici and Mentzer, 2006).

Furthermore, one way of relying on close relationships between firms is the presence of personal relationships between its managers across firms, as it would be difficult for firms to work together if the managers cannot get along (Spekman et al., 1998). Recent studies have shown that managers developing personal relationships within interfirm relationships experience higher trust and mutual loyalty, which ultimately benefit their respective firms, and lead to positive firm-level outcomes such as increased business volume / reduced monitoring costs (Gligor \& Holcomb, 2013; Gligor \& Autry, 2012). However, other researchers argue that personal relationships may also become dangerous for the firms, as there is no assurance that managers relying on personal relationships to promote the interest of the firm will always act in the interest of the firm (Adobor, 2006). Others authors argue that personal relationships between managers across firms may result in a personal loyalty, which can result in corruption and/or embezzlement (Adobor, 2006). Yet, there is a paucity of knowledge on this critical issue. Villena et al. (2011) found that building of a social capital in a buyer-supplier relationship has a very positive impact on the performance of buying firms, however, if social capital is taken to a higher level, it has a potential to reduce the buyer's ability to make an effective and efficient decision. These authors further argued that extreme level of social capital increases suppliers' opportunistic behavior as well. Anderson and Jap (2005) found that close relationships between managers of buying and supplying firms result in higher trust, which further leads to suppliers engaging in opportunism such as shirking.

Extant literature on the buyer-supplier relationship within supply chain context is no exception to this dilemma. Specifically, it does not tell us how personal relationships which are themselves embedded within inter-firm relationships become dangerous for the firms. Gligor and Holcomb (2013) explicitly called to reveal a point when a personal relationship between managers of supply chain member firms become dangerous for the firms. This paper fills this important gap, and it does so by rigorously building a theory in an area of personal relationships. This study aims to discover how personal relationship between managers of buying and supplying firms become dangerous for their respective firms. Consequently, this study asks: How does a presence of personal relationship between managers of 
buying and supplying adversely affect their behaviour in the supply chain context?

The paper is organized as follows: The literature first reviews positive aspects of personal relationships within buyer-supplier relationships; it then critically discusses studies surrounding negative sides of personal relationships within inter-firm relationships. The literature review in this paper includes articles from industrial marketing, strategic management, operations management and sales force context, where a personal relationship focus is taken. A comprehensive review of the literature resulted in a development of many specific findings that contribute to the design of this qualitative study. Due to the limited literature on the phenomena, a grounded theory approach is undertaken. Overall, 16 in-depth qualitative interviews with supply chain managers (senior managers) from Australia manufacturing and service sector are conducted. Furthermore, this study employs Straussian model (1990) as a coding paradigm.

\section{LITERATURE REVIEW}

\subsection{Personal Relationships in Business}

A number of studies in the marketing literature have examined the results of combining personal and business relationships with many of them suggesting that normally positive outcomes occur. For instance, Johnson \& Selnes (2004) conducted a study in Norway and found that creation of value through closer relationships lies in bringing weaker relationships into a portfolio in the first place. Haytko (2004) conducted a study in the USA and found that interpersonal relationships across groups from both sides define firm-tofirm relationships. This author found that Interpersonal relationship exists across categories including strictly business, business friends, and highly personal. Mavondo \& Rodrigo (2001) noted that personal relationships are critical to building and enhancing inter-organizational relationships. These authors further noted that some relationship dimensions may not have significant direct relationships with commitment, but their indirect and total effects may be significant in various industries.

Another research study conducted in the USA on the importance of personal relationships within inter-firm relationships found that that personal relationship between managers provides the impetus for firms entering into a longterm relationship (Xin and Pearce, 1996). Additionally, firms are in a position to gather information about the strengths and interests of a prospective partner through personal relationships present between its executives (Xin and Pearce, 1996). Volkoff et al. (1999) reported that personal ties between individuals are helpful when it came to initiating discussion between the partnering firms. Uzzi (1996) also found that initiation of the business relationship in the garments industry benefited substantially from existing personal ties between individuals. Additionally, Inter-personal relationships between managers often provide the basis for the strong initial trust for a firm to determine whether prospective partners are trustworthy (Zaheer et al., 1998).

Kanter (1994) noted that personal relationships provide an important infrastructure for collaboration, observing that personal relationships help resolve small conflicts before they escalate and concluded that there is no better way out of working out problems except through personal relationships. Kanter (1994) further reported that personal relationships between individuals across firms encourage the sharing of meaningful and helpful information, allowing partners to know each other's intentions and interests and promote cooperative behavior, subsequently overcoming some of the limitations of the contracts. Other authors found that leaders having personal relationships were deemed to be more successful in championing roles. For instance, Kumar and Diesel (1996) revealed that leaders relying on personal relationships within inter-firm relationships were able to provide new ideas and went beyond their normal responsibilities and contributed effectively to project's success. Haytko (2004) argued that it is difficult for personal relationship participants to think about their inter-firm affiliations without first understanding the nature and quality of the associated personal relationship. This is because individuals who adopt the role of linking the organization's internal networks with external sources of information dayto-day experience involve working closely with other individuals.

Doney and Cannon (1997) conducted a study on the importance of personal relationships in inter-organizational relationships in the USA and revealed that development of such relationships increased the frequency of interaction, and created trust by providing buyers with an opportunity to predict their supplier's future behavior with a good level of confidence. In addition, Doney and Cannon (1997) found that personal relationships between partners across firms result in benevolent intentions to each other. Anderson and Weitz (1989) found that personal relationships are important in ensuring the continuity of dyadic relationships. Likewise, Lee et al. (2001) also stressed the importance of personal relationships and suggested that the representatives of each organization should aim to develop a good personal relationship as such relationships also give partner the opportunity to develop better personal understating about each other. Hutt et al. (2000) found that failure to nurture personal relationships generates negative consequences in inter-firm relationships. These authors found that the absence of direct interpersonal contacts between the seniormanagers across firms results in lack of cooperation between them.

Personal relationships have been the subject of much research within the business discipline (Mavondo \& Redrigo, 2001; Gedeon, et al.,2009; Hutt, et al., 2000; Price \& Arnould, 1999; Heide \& Wathne, 2006); however, its application within the SC domain is quite rare. However, limited studies have examined the role of personal relationship and its positive firm-level outcomes. For example, recent research has shown that personal relationships between managers of buying and supplying firms enhanced the business volume of supplying firm as well as reduce monitoring costs of buying firms, as such relationships result in the cultivation of mutual loyalty (Gligor \& Holcomb, 2013). These authors further found that personal relationship between managers of buying and selling logistics services increases trust and develops better personal and business understanding between managers. A unique thing about this study was that it took individual managers as the unit of analysis rather than traditional firm to firm level while studying buyer-supplier relationships in the supply chain (Gligor \& Holcomb, 2013). A major 
contribution of this study was that it introduced a new area such as focusing on individual managers (micro-level analysis) as the unit of analysis, rather than traditional firmto-firm relationships. These authors further encouraged future researchers to focus on individual managers as the unit of analysis while studying buyer-supplier relationships. Gligor \& Autry (2012) conducted another study on the role of personal relationships within buyer-supplier relationships in the supply chain context and found that personal relationships between managers of buying and supplying firms result in the enhanced communication process between the firms. These authors found that personal relationships between managers of buying and supplying firms positively influences firm-to-firm level communication and ultimately results in superior business performance for related organizations. This study also employed individual managers as the unit of analysis while studying buyersupplier relationships.

While the importance of personal relationships between managers of buying and supplying firms is thus well established, other studies argue that, although personal relationships are good for business relationships, the conflict between the business role expectations and the personal role expectations may diminish the above benefits (Grayson, 2007, Price \& Arnould, 1999; Heide \& Wathne, 2006). Adobor (2006), on the other hand, debates that firms who begin to rely heavily on managers' personal relationships within inter-firm relationships should be extremely cautious, as such relationships may create different sort of financial interests for managers. This author further warns that there is no such assurance that managers relying on personal relationships within inter-firm relationships to promote the interest of the firm will always use such relationships in the best interest of the firm. Instead, they may begin to exploit such relationships. Villena et al. (2011) debates that strong personal relationships between managers of buying and supplying firms can result in suppliers behaving opportunistically to gain competitive advantage from their respective firms. On the other hand, Gligor and Holcomb (2013) state that mutual loyalty between managers across firms as a result of personal relationships may become stronger in nature, leaving firms in a vulnerable situation. Anderson \& Jap (2005) also argues that personal relationships between managers of buying and supplying firms may lead to corruption and embezzlement. Unfortunately, supply chain literature on buyer-supplier relationships is mute on this critical issue yet. Specifically, it does not exactly tell us how personal relationships between managers of buying and supplying firms, which appear to be doing great for the respective firms go wrong and put the fate of firms in danger.

\section{METHODOLOGY}

Limited knowledge on the phenomena of interest lends itself to a theory building through a grounded theory approach (Glaser and Strauss, 1967). Additionally, grounded theory is also a recommended methodology for building a theory on behavioral and various social processes (Flint et al., 2005). Logistics and Supply Chain discipline also encourages the use of grounded theory, when studying phenomena with complex behavioral dimensions (Mello and Flint, 2009).

\subsection{Study Sample, Sampling and Data Collection Method}

\subsubsection{Study Sample}

Overall, 16 supply chain managers (8 supply chain managers from buying firms and 8 supply chain managers from different supplying firms) were interviewed from 16 Australian organizations/companies. Moreover, the supply chain managers interviewed were senior managers (principals) directly involved in the process of buying or selling products and services; and having knowledge about personal relationships within the context of buying and selling. The final sample included senior managers from multiple industries to facilitate theory building. Further details are presented in Table 1. It is also important to emphasize that respondents did not report using personal relationships as a means to an end. Rather they simply indicated the negative consequences for firms involved, with the presence of personal relationships between managers across firms.

Table 1 below shows five different columns. The first column from the extreme left shows codes of the participants. The second column outlines types of organizations, which participated in this study. The third column exhibits details of informants while the next two columns present details pertaining to principals and agents.

\subsubsection{Sampling}

The following process was used to recruit the participants: the first senior manager from the buying firm and supplying was selected using purposive sampling. At the end of the interviews, these respondents were asked to facilitate contact with the senior manager from another firm having an idea of how personal relationships work in interfirm relationships (snowball sampling). Following this, I relied on theoretical sampling technique to identify who to interview next.

\subsubsection{Data Collection}

Data was collected through in-depth qualitative interviews to facilitate theory building. Overall, 16interviews were conducted- the study represents 16 cases. Theoretical saturation was attained after 16 interviews, as additional interviews yielded no new information. Based on this fact, and in consideration of standards set forth in previous research, 16 interviews were found to be enough for data collection purposes (McCracken, 1988 suggest that it is common to interview eight informants to reach saturation). Data was also collected through feedback reports on the researcher's interpretations. It is worth mentioning that memos of observations were created and documents obtained from identified actors were drawn on. An interview protocol is provided in Appendix A for further information. 
Table 1 Study Sample

\begin{tabular}{|c|c|c|c|c|}
\hline \multicolumn{2}{|c|}{ Suppliers } & Principal & Agent \\
\hline Codes & $\begin{array}{c}\text { Organization } \\
\text { Type }\end{array}$ & Supplier of Logistics Services & Informant & Shief Operating Officer \\
\hline S2 & Supplier of Frozen Food & Managing Director & Same as informant & Sales Manager \\
\hline S3 & Supplier of Confectionary Items & $\begin{array}{c}\text { Senior Customer Services } \\
\text { Manager }\end{array}$ & Same as informant & Customer Service Manager \\
\hline S4 & Supplier of Logistics Services & Accounts Manager & Same as informant & Operations Manager \\
\hline S5 & Supplier of Logistics Services & Senior Operations Manager & Same as informant & Operations Manager \\
\hline S6 & Financial Services Provider & $\begin{array}{c}\text { Senior } \\
\text { Customer Service Manager }\end{array}$ & Same as informant & Sustomer \\
\hline S7 & Financial Services Provider & Senior Service Manager & Same as informant & Sales Manager \\
\hline S8 & Educational Services Provider & Customer Service Manager & Same as informant & Sales Manager \\
\hline
\end{tabular}

\begin{tabular}{|c|c|c|c|c|}
\hline \multicolumn{5}{|c|}{ Buyers } \\
\hline Codes & $\begin{array}{c}\text { Organization } \\
\text { Type }\end{array}$ & Informant & Principal & Agent \\
\hline B1 & Manufacturer of Chemical Products & $\begin{array}{c}\text { Senior Procurement and Logistics } \\
\text { Manager }\end{array}$ & Same as informant & Procurement Manager \\
\hline B2 & Manufacturer of Coffee Machines & Procurement and Trade Manager & Same as informant & Procurement Manager \\
\hline B3 & Manufacturer of Leather Garments & Operations Manager & Same as informant & Area Operations Manager \\
\hline B4 & Manufacturer of Solar Panels & Senior Operations Manager & Same as informant & Operations Manager \\
\hline B5 & Manufac. of Construction Materials & Senior Procurement Manager & Same as informant & Procurement Manager \\
\hline B6 & Manufacturer of Toys & Senior Procurement Manager & Same as informant & Procurement Manager \\
\hline B7 & Manufacturer of confectionary Items & Senior Procurement Manager & Same as informant & Procurement Manager \\
\hline B8 & Buyer of Web Services & Senior Procurement Manager & Same as informant & Procurement Manager \\
\hline
\end{tabular}

\subsection{Data Coding Analysis}

To code and analyse data, Strauss and Corbin (1998) suggest three different types of coding in grounded theory. These are open coding, axial coding, and selective coding. Also, as this study crosses two level of analysis - personal and organizational relationships, it is important to mention that the unit of analysis in this study is individual managers. Additionally, all interviews were transcribed and analyzed on a line-by-line basis. In order to fully maintain the objectivity of the data collection and coding process, two additional analysts were invited to help with the coding and detailed analysis of data. Overall, three analysts examined the data.

During the open coding, all three analysts segregated data into different incidents, ideas, acts and events and further and assigned a code representing these. Furthermore, qualitative research computer software (NVIVO) was used to facilitate the coding process. NVIVO allowed each analyst to code transcripts on their own and merge the files later into one document to compare codes, once analysis process is finished. NVIVO also facilitated the process of comparing inter-coder reliability. Furthermore, all three analysts kept a detailed record (i.e. analysts' interpretations, questions, and directions). During the coding process, when any differences occurred, all three analysts decided to reach each other's theoretical memos to understand why certain there has been a difference in concepts and each analyst's interpretation.
This rigorous process made sure that the interpretations of each analyst emerged from completely logical and impartial thought processes. This iterative process by each analyst to individually code the transcripts continued as additional interviews were conducted and new transcripts were made available. The coding process was not considered complete until all analysts reached consensus on each code. Following the described process 172 open codes were generated such as higher Initial trust, conflict of interest, personal reputation, exploitation, nepotism

Following this, when analysts came across other objects events sharing some common characteristics, each analyst placed it under the same code. Besides this, another important feature of grounded theory was also employed termed as comparative analysis (Strauss and Corbin 1990). In this process, each incident was compared with other incidents at the property to find out any level for similarities and differences and further placed into a category. Following this, analysts grouped concepts into themes/categories (e.g., higher agency costs) for detailed content analysis. When analysts developed categories through reliance on open coding, a rigorous content analysis was conducted around each category, one at a time. This process is known as axial coding. The purpose of this step is to begin the process of reconstructing data that was broken down during the process of open coding. In axial coding, analysts related categories with each other to develop more dense and detailed 
explanation of the phenomena focusing on how categories relate and cross crosscut. During this process, all three analysts continued to make constant and theoretical comparisons and make use of the NVIVO described previously. Finally, a selective coding process was employed; which is another essential feature of coding process prescribed by Strauss and Corbin (1998). This step was employed to limit the coding process to core variables of interest that have emerged from the study. The final coding process resulted in an emergence of a theoretical model (Figure 1), listing four types of actions as well as its corresponding firm-level outcomes (themes) as a result of personal relationships between managers of buying and supplying firms in the supply chain.

Flint et al. (2002) suggest that the trustworthiness of the research in qualitative studies should be assessed by thoroughly considering two sets of criteria. Researchers from social sciences mainly found in marking state that that credibility, transferability, dependability, conformability, and integrity are the first area of focus (e.g. Hirschman, 1986; Lincoln and Guba, 1985). These criteria were evaluated thoroughly as follows: First of all, a summary of initial interpretations was provided to participants for feedback (credibility). Credibility was also achieved in this study through prolonged engagement in the field. Time in the field is spent until data from multiple participants reaches saturation. Saturation is considered achieved when further probing yields no new information. Data collected in interviews is complemented by relevant documentation such as firm's performances. Second, theoretical sampling was used (transferability); third, specific guidelines (such as constant comparison used in grounded theory) for collection and analyses of the data was strictly followed (dependability); fourth, an independent auditor was used to confirm interpretations prior to journal submission (conformability). This auditor followed through the study in order to understand exactly how and why decisions were made. The auditor considered the whole process of research along with the data, findings, and interpretations; and fifth, participants were assured of anonymity (integrity).

Second, the criteria of generality, understanding, control, and fit emerged from the grounded theory literature itself (Strauss and Corbin, 1990). These criteria were assessed in the following manner: interviews were quite lengthy and deep in nature which allowed for different aspects of the phenomenon to emerge (generality);

summaries of interview transcripts were provided to participants and asked if it reflected their stories (understanding); participants also had control over some variables (control); and finally, the criteria of fit was addressed through the rigorous methods mentioned earlier to control for credibility, dependability, and conformability. Table 2 provides further explanation as for how trustworthiness of the study was achieved.

\section{RESULTS}

As depicted in Figure 1, the grounded theory analysis of field data suggested that managers engaged in three different types of opportunistic actions, leading to higher agency costs for the respective firms, as a result of personal relationships between managers of buying and supplying firms in the supply chain.

\subsection{Theme: Higher Agency Costs}

Respondents' stories thoroughly stated that their managers who relied on personal relationships within interfirm relationships to promote the interest of the firm engage in three different opportunistic actions.

These are: demanding higher sales commissions, demanding higher bonuses, and demanding a higher salary from their respective firms. Each of the specific opportunistic action is explained below in sections 4.1.1, 4.1.2 and 4.1.3.

\subsubsection{Action 1: Demanding Higher Sales Commission}

Five senior managers (S1, S2, B1, B2 and S8) warned supplying firms that Sales Managers having strong personal relationships with Procurement Managers are in a position to switch from one supplying firm to another, collecting higher sales commission each time, based on the strength of their ability to take their customers (i.e. Procurement Managers) with them to the new firm.

The following quote testifies to the fact: My sales manager told me [paraphrasing the Sales Manager] "other supplying firms are offering me higher sales commission because I can take customers with me to the new firm due to the presence of strong friendship with them. So, I will only continue to work for you if firm raises my sales commission" (Chief Operating Officer, Web Application Service Provider, S1).

Other interviews with two senior managers from supplying firms (S7, S8) provided support to the above findings. These informants argued that strong interpersonal relationships can cause problems in sales when sales managers from such close relationships with clients that they are able to take these clients that they are able to take these clients with them when they leave the firm.

These informants reported that a sales manager in their firm was in a position to take a key Purchasing Manager with him to the new firm because of his close friendship with the Purchasing Manager. Subsequently, the Sales Manager demanded higher sales commission, because he was confident enough that if the firm did not fulfill his demand, he would switch over and take that Purchasing Manager with him. These Senior Sales Managers further mentioned that their firm was not in a position to lose one of its biggest clients, and subsequently granted the Sales Manager higher sales commission, which increased the costs of the firm, however, that increase was far better than losing a customer.

Another interview with a Senior Services manager from a firm providing financial services provided supports to the above findings

Sales Manager in my firm demanded a raise in his commission; otherwise, he warned us that he would take customers with him to the new firm, giving another firm a competitive advantage. This was just because my Sales Manager had a very strong personal relationship with some of our very important clients. Subsequently, the firm raised the Sales Manager's commission (Senior Service Manager, Financial Service Provider, S8) 


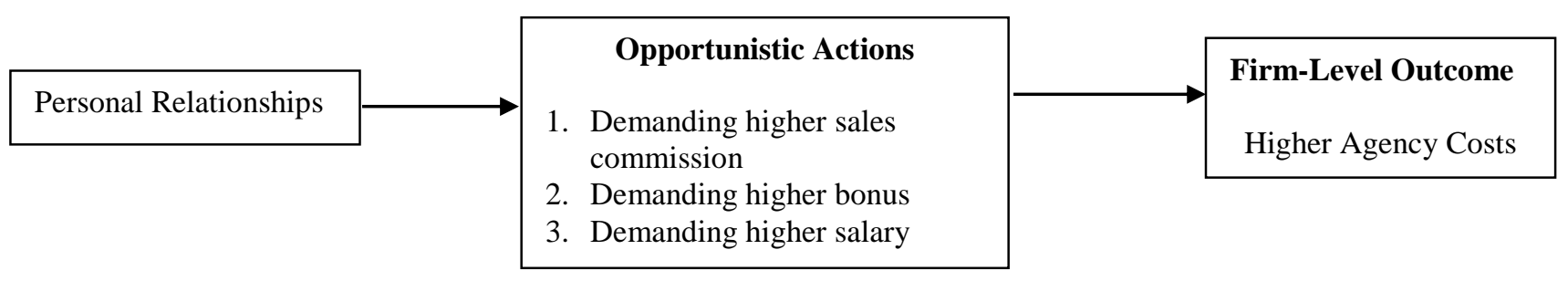

Figure 1: Proposed Theoretical Model

Table 2 Theme I: Higher agency costs theme

\begin{tabular}{|l|l|l|}
\hline \multicolumn{1}{|c|}{ Action } & $\begin{array}{c}\text { Number/percentage of participants } \\
\text { discussing the property }\end{array}$ & \multicolumn{1}{c|}{ Additional Sample Quotes } \\
\hline Demanding Higher Sales Commission & $\begin{array}{l}\text { Participants: S1, S2, S4, B1, B2, B3, } \\
\text { S7, and S8. }\end{array}$ & $\begin{array}{l}\text { My sales manager demanded higher sales } \\
\text { commission or argued that he will take our biggest } \\
\text { client with him to the new firm because procurement } \\
\text { manager employed there is his best friend (S1). }\end{array}$ \\
\hline Demanding Higher Bonuses & $\begin{array}{l}\text { Participants: B5, S1,S3, S5, S6, S7, } \\
\text { S8 and B6 }\end{array}$ & $\begin{array}{l}\text { When managers become indispensable for the firms } \\
\text { because of their strong friendly ties with managers } \\
\text { from the partnering firms, they exploit their } \\
\text { indispensability by demanding higher bonuses in } \\
\text { company's annual profits (S8) }\end{array}$ \\
\hline Demanding Higher Salary & $\begin{array}{l}\text { Participants: S1, S3, S5, B3, B4, B7 } \\
\text { and B8 }\end{array}$ & $\begin{array}{l}\text { Managers become abusive and demand a raise in their } \\
\text { salaries once they know that firms cannot survive } \\
\text { without relying on their strong personal relationships } \\
\text { (S3) }\end{array}$ \\
\hline
\end{tabular}

\subsubsection{Action II: Demanding Higher Bonuses}

Three informants (S3, S6 and S8) stated that an agent in their firm who was in a strong friendly relationship with their main client became confident that if he resigns from his position, clients will not grant any new business to the supplying firm because those clients are Sales Manager's best friend. These informants emphasized that there were a strong bonding and chemistry between their Sales Manager and the clients he had been dealing with, due to the strong friendship between them. These informants further stated that their Sales Manager eventually behaved opportunistically and commanded a higher bonus or otherwise threatened to resign from his position, meaning that those main clients would not award the supplying firm any business. Nevertheless, these informants argued that the cost is borne by the firm while granting the Sales Manager a higher bonus was much less than the cost firm would have borne if they had lost big clients the senior managers' narratives informed that managers, whose personal ties became indispensable for their firm, exploited their indispensability by demanding higher bonuses. Following quote testifies to this:

\section{Well, I can certainly tell you that when managers know that firms cannot survive without relying on their personal relationships with the partnering firms. They begin to demand other financial incentives such as higher bonuses (Senior Customer Services Manager, Supplier of Confectionary Items,S3)}

\subsubsection{Action III: Demanding Higher Salary}

Another interview with the senior manager (B8) revealed that while it is easy for his buying firm to determine a prospective partner's capability to deliver on the goals of the long-term relationship, it is not easy to determine whether they are trustworthy. And this is where the role of a personal relationship between managers comes into play. However, when they realize that firms cannot have access to the prospective firm's trustworthiness, without relying on their existing personal relationships with key supplying managers, they engage in exploitation, which increases the direct cost of the firm.

A senior manager (S5) also argued that one important limit to relying on personal relationships of managers is that there are no guarantees that they will always act in the foremost interest of the firm. Notably, when managers become indispensable for their firm, because of their strong personal relationships, they engage in exploitation and demand higher financial incentives such as salaries, which results in higher costs for the firms involved.

\section{Managers become indispensable for the firms because of their strong personal relationships and exploit their indispensability by commanding higher salary, which leaves firms in vulnerable situation (Senior Operations Manager, Web Application Service Provider, S5)}

Another interview with a Senior Operations Manager (B12) of a firmmanufacturing Health Care Products reported that personal relationships (i.e. friendship) usually make it possible for managers to develop a better understanding of the other party's business needs beyond the expected level by the respective supply chain partner. Consequently, managers sometimes gain access to business information beyond the expected level and exploit this situation with their 
respective firms by demanding a higher salary. Otherwise, they begin to share such information with competitors purposefully.

Additional interview with a Senior Customer Services Manager (S3) of a firm supplying Confectionary Products reported that personal relationships between managers across firms result in better personal and business understanding. This informant further stated that personal relationships basically help both parties to better address work-related and personal issues, therefore performing better. However, there is a potential negative consequence for firms as a result of such an understanding. For instance, managers use an enhanced understanding of the other party's characteristics to manipulate them. Additionally, personal relationships (i.e. friendship) allow managers to develop an understanding of the other party's business needs beyond the level desired by the respective supply chain partner. Consequently, managers gain access to business information beyond the expected level and exploit this situation with their respective firms by demanding a higher salary.

\section{RESEARCH CONTRIBUTIONS}

\subsection{Contribution to Theory}

While previous studies in the supply chain literature have addressed how personal relationships which are themselves embedded within inter-firm relationships generate positive outcomes for the firms (Gligor and Holcomb, 2013; Gligor and Autry, 2012), this is perhaps, the first study which examines the dark sides of personal relationships in the supply chain context. First, this study contributes to the supply chain literature by outlining different forms of opportunistic behaviours that managers engage in, when they rely on personal relationships within supply chain relationships to promote the interest of the firm. Specifically, results reveal that managers exploit personal relationships by demanding higher financial incentives (salary, bonus, commissions etc.). Second, it reveals specific negative outcome such as higher agency costs for the firms as a result of these opportunistic actions. Results, on the whole, suggest that personal relationships have a potential to deviate managers' interest from the firm, which can further put the fate of firm in danger. This study also builds on previous study by Adobor (2006). For instance, this author argued that managers can use personal relationships to look after their personal interests, but it did not outline the nature of such behaviours. This study builds on this body of literature by outlining specific opportunistic actions that managers engage in, where a personal relationship focus is taken.

\subsection{Contribution to Practice}

Considering the key role that personal relationships play in business relationships, it is vital that firms have strategies in place to cope the misuse of personal relationships. Carefully managing personal relationships by completely understanding wherein the business relationship they fit the most offers an important means for mitigating the adverse consequences of personal relationships. Of course, managers' opportunistic behavior has a potential to disrupt the organizations operating in the supply chain, Supply chain organizations can also have a difficult time replacing the individual who shares strong personal relationships, which can affect their competitiveness and firms may have to compromise on low-quality products/services. The key assumption for firms here is that most of the benefits that can be derived from personal relationships between managers are likely to be realized in the early phase of the business relationship. At the same time, most of the negative consequences associated with personal relationships are likely to occur in the later stage of the business relationship. These findings are consistent with other studies that individual attachments are important early in a relationship but begin to diminish in significance over time (Adobor, 2006; Seabright, Levinthal, and Fichman, 1992).

Senior management can employ the following strategies in order to mitigate the negative effects arising from personal relationships within inter-firm relationships:

i. Monitoring Personal Relationships;

ii. Bonding Costs by Agents;

iii. Defining Boundary Line of Personal Relationships;

iv. Developing Safety Measures;

v. Rotating Managers;

\subsection{Monitoring Personal Relationships}

Managers developing personal relationships with their counterparts across firms are likely to experience a higher conflict of interests as compared to managers who do not develop personal relationships. Firms, should, therefore, strictly monitor such relationships. Gligor \& Esmark (2015) also suggest that firms should aim to carry out monitoring of such relationships, depending on the size and culture of the company. For example, managers should be more frequently asked to disclose any potential conflicts of interest when selecting new suppliers. Such self-reporting structure is depended on the level of trust between senior management and the managers and can help senior management better understand if a manager's specific relationship with a manager across firm could create agency problem. Firms should also closely analyze the business dealing between such managers across firms to make sure that managers are not taking any undue advantage of personal relationships at the cost of the firm.

\subsection{Bonding Costs by Agents}

Bonding costs are incurred by the agent. An agent may commit to contractual obligations that limit or restrict the agent's activity. For example, a manager may agree to stay with a company even if the company is acquired by a competitor. The manager must forego other potential employment opportunities. That implicit cost would be considered an agency bonding cost (Eisenhardt, 1989).

Sales Managers can exploit the opportunity as it arises (such as switching employers) based on the strength of their ability to take their customers with them due to the presence of strong personal relationships with them. The supplying firms should, therefore, use bonding costs as a mechanism to prevent the abuse of such relationships. In other words, contracts between the supplying firms and sales managers who rely on personal relationships within inter-firm relationships should be designed in such a way that it put restrictions on sales managers' ability to switch. Doing so will prevent sales managers from exploiting any situation in 
their favor arising as a result of personal relationships, which can increase agency costs.

\subsection{Defining Boundary Line of Personal Relationships}

Firms who do not have enough policies in place to determine the boundary line of developing personal relationships between managers across firms should be extremely cautious. Gligor \& Holcomb (2013) also suggest that having policies regarding the extent to which personal relationships with managers across firms as a source of competitive advantage for firms will serve as an important mean to mitigate agency costs. Firms should, therefore, make every effort to establish such policies. Such policies can be mentioned in company's handouts or during induction. Furthermore, if senior management finds out that one of their managers is acting inappropriately within the confines of personal relationships, they should take appropriate action immediately.

\subsection{Developing Safety Measures}

Firms should aim to develop safety measures to protect against the agency problem that develops as a result of personal relationships. Senior management from the buying firm should review business relationship with the supplying firms more frequently to verify that the rates their managers are offering to their friends are competitive and align with the firm's policies. This verification should be further done to make sure that products received from such suppliers are of quality standard and meet the firm's expectations. Senior management at the supplying firms, on the other hand, should verify that managers in the firm do not give any inconsistent favors to the managers from the buying firms such as doing free projects.

\subsection{Rotating Managers}

Buying firms should also consider the more frequent $\mathrm{e}$ frequent rotation of managers to prevent the development of personal loyalty with managers from the supplying firms. Allowing new managers to nurture personal relationships with their counterpart from the supplying firm will be proactive and reduce the possibility of the development of personal loyalty, which increases opportunity costs of the buying firms (Gligor \& Holcomb, 2013; Gligor \& Autry, 2012). However, senior management at both buying and supplying firm should be extremely careful while rotating managers as personal relationships are mutually beneficial for both parties. It is vital that if senior management at both firms will allow its managers to interact with their supply chain counterparts they enjoy working with, this will lead to higher productivity rate and better job satisfaction, which will ultimately benefit related firms.

\subsection{Conclusion and Future Research}

Senior managers argued that it is possible to streamline buyer-supplier relationships by leveraging personal relationships. Furthermore, the ability of firms to effectively manage personal relationships within inter-firm relationships can be a source of a competitive advantage for firms. It is, therefore, important to understand that personal relationship between managers across firms can play a significant role in inter-firm relationships. Alternatively, it is worth stressing that structuring inter-firm relationships that completely eliminate the role of personal relationships may also lead to serious consequences as placing too much faith in them.

While the findings from this qualitative research contribute to the understanding of how personal relationships affect managers' ability to act in firm's best interest, the results are based on the perceptions and opinions of a limited number of participants. This is certainly a limitation of qualitative studies. As this study builds theory, its results are not generalizable to a broader population. As this study proposes a theory (model) based on the experiences of a relatively small sample of Australian senior managers, it is important the future research empirically tests the model in other national contexts in a way that demonstrates its generalizability or otherwise.

\section{REFERENCES}

Adobor, H. (2006). The role of personal relationships in inter-firm alliances: Benefits, dysfunctions, and some suggestions. Business Horizons, 49(6), pp. 473-486.

Anderson, E., \& Robertson, T. S. (2005). Inducing multiline salespeople to adopt house brands. Journal of Marketing, 59 (2), pp. 16-31

Anderson, E., \&Weitz, B. (1989). Determinants of continuity in conventional industrial channel dyads. Marketing Science, 8(4), pp. 310-323.

Autry, C. W., and Golicic, S. L. (2010). Evaluating buyer-supplier relationship-performance spiralsA longitudinal study. Journal of Operations Management, 28(2), pp. 87100.

Bitner, M. J. (1990). Evaluating service encounters the effects of physical surroundings and employee responses. Journal of Marketing, 54 (2) pp. 69-82.

Bruner, R., and Spekman, R. (1998). The dark side of alliances: Lessons from Volvo-Renault. European Management Journal, 16(2), pp. 136-150.

Celsi, R. L., Rose, R. L., and Leigh, T. W. (1993). An exploration of high-risk leisure consumption through skydiving. Journal of Consumer Research, 20(1), pp. 1-23.

Doney, P. M., \& Cannon, J. P. (1997). Trust in buyer-seller relationships. Journal of Marketing, 61 (2), pp. 35-51.

Echchakoui, S. (2014). Salesperson profitability in relationship marketing. Journal of Modelling in Management, 9(3), pp. 306-323.

Fischer, C. S. (1982). To Dwell Among Friends: Personal Networks in Town and City. University of Chicago Press.

Flint, D. J., Larsson, E., Gammelgaard, B., and Mentzer, J. T. (2005). Logistics innovation: a customer value-oriented social process. Journal of Business Logistics, 26(1), pp. 113147.

Flint, D. J., Woodruff, R. B., and Gardial, S. F. (2002). Exploring the phenomenon of customers' desired value change in a business-to-business context. Journal of Marketing, 66(4), pp. 102-117.

Glaser, B. G. A. L. (86). Strauss (1967): The Discovery of Grounded Theory: Strategies for Qualitative Research. London: Edenfeld and Nicholson, 81.

Gligor, D. M., \& Holcomb, M. (2013). The role of personal relationships in supply chains. International Journal of Logistics Management, 24(3), pp. 328

Gligor, D. M., and Autry, C. W. (2012). The role of personal relationships in facilitating supply chain communications: A qualitative study. Journal of Supply Chain Management, 48(1), pp. 24-43. 
Golicic, S. L., and Mentzer, J. T. (2006). An empirical examination of relationship magnitude. Journal of Business Logistics, 27(1), pp. 81-108.

Grayson, K. (2007). Friendship versus business in marketing relationships. Journal of Marketing, 71(4), pp. 121-139.

Haytko, D. L. (2004). Firm-to-firm and interpersonal relationships: Perspectives from advertising agency account managers. Journal of the Academy of Marketing Science, 32(3), pp. 312-328.

Heide, J. B., \&Wathne, K. H. (2006). Friends, businesspeople, and relationship roles: A conceptual framework and a research agenda. Journal of Marketing, 70(3), pp. 90-103.

Hirschman, E. C. (1986). Humanistic inquiry in marketing research: philosophy, method, and criteria. Journal of Marketing Research, 23 (3) pp. 237-249.

Hoskin, R. (1983). Opportunity Cost and Behavior. Journal of Accounting Research, 21(1), pp. 78-95.

Hutt, M. D., Stafford, E. R., Walker, B. A., \&Reingen, P. H. (2000). Case study: defining the social network of a strategic alliance. MIT Sloan Management Review, 41(2), pp. 51.

Johnson, M. D., and Selnes, F. (2004). Customer portfolio management: Toward a dynamic theory of exchange relationships. Journal of Marketing, 68(2), pp. 1-17.

Kalra, A., Shi, M., and Srinivasan, K. (2003). Salesforce compensation scheme and consumer inferences. Management Science, 49(5), pp. 655-672.

Kalwani, M. U., and Narayandas, N. (1995). Long-term manufacturer-supplier relationships: do they pay off for supplier firms? Journal of Marketing, 59 (1), pp. 1-16.

Kanter, R. M. (1994). Collaborative advantage: The art of alliances. Harvard Business Review, 72(4), pp. 96-108.

Kumar, K., \& Van Dissel, H. G. (1996). Sustainable collaboration: managing conflict and cooperation in interorganizational systems. MIS Quarterly, 20 (3), pp. 279-300.

Lee, D. J., Pae, J. H., \& Wong, Y. H. (2001). A model of close business relationships in China (guanxi). European Journal of Marketing, 35(1/2), pp. 51-69.

Lincoln, Y. S., and Guba, E. G. (1985). Naturalistic Inquiry, 75. Sage.

Mavondo, F. T., \& Rodrigo, E. M. (2001). The effect of relationship dimensions on interpersonal and interorganizational commitment in organizations conducting business between Australia and China. Journal of Business Research, 52(2), pp. 111-121.

McCracken, G. (1988). The Long Interview, 13. Sage.

Mello, J., and Flint, D. J. (2009). A refined view of grounded theory and its application to logistics research. Journal of Business Logistics, 30(1), pp.107-125.

Michael D., Fred S. (2004) Customer Portfolio Management: Toward a Dynamic Theory of Exchange Relationships. Journal of Marketing, 68(2), pp. 1-17.

Price, L. L., \&Arnould, E. J. (1999). Commercial friendships: service provider-client relationships in context. Journal of Marketing, 63 (4), pp. 38-56.

Rust, R. T., \&Zahorik, A. J. (1993). Customer satisfaction, customer retention, and market share. Journal of Retailing, 69(2), pp. 193-215.

Silver, A. (1990). Friendship in commercial society: Eighteenthcentury social theory and modern sociology. American Journal of Sociology, 95 (6), pp. 1474-1504.

Strauss, A. L. (1987). Qualitative Analysis for Social Scientists. Cambridge University Press.

Strauss, A., and Corbin, J. (1990). Basics of Qualitative Research, 15. Newbury Park, CA: Sage.

Uzzi, B. (1996). The sources and consequences of embeddedness for the economic performance of organizations: The network effect. American SociologicalReview, 61 (4), pp. 674-698.

Villena, V. H., Revilla, E., \& Choi, T. Y. (2011). The dark side of buyer-supplier relationships: A social capital perspective. Journal of Operations Management, 29(6), pp.561-576.

Volkoff, O., Chan, Y. E., and Newson, E. P. (1999). Leading the development and implementation of collaborative interorganizational systems. Information and Management, 35(2), pp. 63-75.

Xin, K. K., and Pearce, J. L. (1996). Guanxi: Connections as substitutes for formal institutional support. Academy of Management Journal, 39(6), pp. 1641-1658.

Zaheer, A., McEvily, B., and Perrone, V. (1998). Does trust matter? Exploring the effects of inter-organizational and interpersonal trust on performance. Organization Science, 9(2), pp. 141159 
Opening

\section{APPENDIX A: INTERVIEW PROTOCOL}

Thank you for taking a time from your busy schedule to meet with me. Please allow me few moments to briefly explain you the research project.

I am from XXXXX University and I am trying to understand the role of personal relationships that buyers and suppliers of products and services rely on within the inter-firm relationship. I aim to interview you because I believe I can learn a lot from your personal experience.

You are assured that this interview will be very open and friendly. There are no right and wrong answers to this; basically, you are an expert in your area and my sole intention is to learn from your career experience. This interview is strictly confidential and with your permission, I would like to tape-record this interview.

1. Could you please tell me about your position here (firm name)?

2. How long have you been associated with this organization?

3. What are your current responsibilities?

4. Whom do you report to?

5. Amongst the key managers that work in your firm, can you think of anyone of them who developed a personal relationship with a manager from the partnering firm?

6. Could you please clearly place such manager in your mind?

Please tell me about one of these relationships:

How did the personal relationship develop?

7. Now could you think of any situation when you felt that such manager was taking undue advantage of the personal relationship?

8. I would like to know more about how personal relationships encourage him to act opportunistically?

9. How did it negatively impact on the firm?

Floating Prompts

Could you please tell me a little bit more about this?

I would like you to explain more on that please?

Really very interesting. Please continue

Can you give me an example?

Wrap up

Thank you very much indeed for this interview. I will provide you a copy of our report when I am done collecting and analyzing the data in near future. If you have any questions please feel free to contact me. 


\section{APPENDIX B}

Table 3 Trustworthiness of the study and findings (Flint et al., 2005)

\begin{tabular}{|c|c|}
\hline Interpretive criteria & Grounded theory criteria \\
\hline $\begin{array}{l}\text { Credibility } \\
\text { Extent to which the results seem to be acceptable representations } \\
\text { of the data }\end{array}$ & $\begin{array}{l}\text { Fit } \\
\text { Extent to which findings fit with the substantive area under } \\
\text { investigation }\end{array}$ \\
\hline $\begin{array}{l}\text { Transferability } \\
\text { Extent to which the findings in a context have applicability in } \\
\text { other contexts }\end{array}$ & $\begin{array}{l}\text { Understanding } \\
\text { Extent to which participants believe the results to be representations } \\
\text { of their worlds }\end{array}$ \\
\hline $\begin{array}{l}\text { Dependability } \\
\text { The extent to which the findings be the same if the study was } \\
\text { repeated with similar subjects and context }\end{array}$ & $\begin{array}{l}\text { Generality } \\
\text { Extent to which findings discover multiple aspects of the phenomenon }\end{array}$ \\
\hline $\begin{array}{l}\text { Conformability } \\
\text { The extent to which the findings are determined by the subjects } \\
\text { and context and not by the researcher's bias and motives }\end{array}$ & $\begin{array}{l}\text { Control } \\
\text { Extent to which organizations can influence aspects of the theory }\end{array}$ \\
\hline $\begin{array}{l}\text { Integrity } \\
\text { Extent to which the findings are influenced by participant } \\
\text { misinformation }\end{array}$ & \\
\hline
\end{tabular}

Atif Saleem Butt holds PhD in Supply Chain Management from Monash University, Australia. Atif has over 5 years of experience working with academic and industry. His current research focuses on behavioural operations and supply chain management. 